\title{
Wage Inequality Within and Between Occupations'
}

I Håvard Helland

Professor, The Centre for the Study of Professions, Oslo and Akershus University of Applied Sciences, Norway

\section{Thijs Bol}

Assistant Professor, Department of Sociology, University of Amsterdam, The Netherlands

\section{Ida Drange ${ }^{2}$}

Senior Researcher, Work Research Institute, Centre for Welfare and Labour Research, Oslo and Akershus University of Applied Sciences, Norway

\begin{abstract}
Western countries, including Scandinavian nations, have witnessed an increase in wage inequality over the past decades. Recent studies attribute rising wage inequality in the United States and United Kingdom primarily to between-occupation inequality, while changes in within-occupation wage inequality were less important for the overall growth. We investigate this hypothesis in the Nonwegian context. Our results show a slight increase in inequality from 2003 to 20 I2, mostly accounted for by between-occupational wage inequality. Occupations became a more important determinant of wages, but the increase in total wage inequality was small. In order to explain trends in wage inequality, we turn to three occupational characteristics: licensure, unionization, and credentialization.
\end{abstract}

\section{KEYWORDS}

Between-occupation wage inequality / Credentialization / Licensure / Occupational closure / Unionization / Within-occupation wage inequality

\section{Introduction}

ost western countries have witnessed increasing inequality in wage income and wealth in recent decades (Piketty, 2014; Stiglitz, 2012). This trend holds true even in Scandinavian countries, such as Norway, albeit from comparably low inequality levels (Cholezas \& Tsakloglou, 2009; Markussen \& Røed, 2016; Mastekaasa, 2011;). Here, we study the role of occupations in this development. Occupations are often seen as the backbone of the class structure (e.g., Goldthorpe, 1987, p. 29) and are central to most studies on social inequality and social stratification (e.g., Weeden \& Grusky, 2005), to operationalizations of social class (e.g., Erikson \& Goldthorpe, 1993; Oesch, 2006; Wright, 1997), and to scales of socioeconomic status (e.g., Prandy, 1990). If occupations are this crucial to life chances and social inequalities, they probably have played some

\footnotetext{
${ }^{1}$ You can find this text and its DOI at https://tidsskrift.dk/njwls/index.

${ }^{2}$ Corresponding author: ida.drange@afi.hioa.no. This research was funded by the Norwegian Research Council, grant number 237039.
} 
role in the development toward increasing wage differences. Researchers have established that the rise in wage inequality in the United States (US) (Mouw \& Kalleberg, 2010) and United Kingdom (UK) (Williams, 2013) is found primarily between occupations, with slower growth of within-occupation wage inequality (Mouw \& Kalleberg, 2010).

Rising wage inequality has numerous explanations. Stiglitz (2012) highlights rent-seeking activities as an important explanation for the rising wage gap. While there are different ways by which rents are accrued, an important mechanism is via creating a monopoly on a service or product (Weeden \& Grusky, 2014). Occupational licenses are one example on how to create a monopoly on occupational tasks (Stiglitz, 2012, p. 54). ${ }^{1}$ This article examines how three institutions of occupational closure affect wage inequality in Norway. More specifically, we investigate how occupational licensure, credentialization, and unionization correlate with the (growing) earnings differences between and within occupations and in different parts of the income distribution. Our hypothesis is that closure institutions increase the average wage levels in occupations and equalize the distribution of residual inequality within occupations.

The current article complements previous research in two ways. First, it provides evidence on the trends in between- and within-occupation wage inequality in Norway, where this decomposition has not previously been performed. Both the US and UK are liberal market economies, whereas Norway has a coordinated market economy with lower overall inequality levels and a centralized bargaining system.

Second, we examine the role of licensure, credentialization, and union density for between- and within-occupation wage inequality. Research on occupational closure documents higher average wage levels from licensure and union density in the US (Humphris et al., 2010; Kleiner \& Krueger, 2010; Weeden, 2002), the UK (Bol \& Weeden, 2015; Humphris et al., 2010), Germany (Bol \& Weeden, 2015), and Norway (Bol \& Drange, 2016). The effects of these institutions on (changes in) aggregate wage inequality, however, remain unexplored.

We analyze public administrative register data on the working population from 2003 to 2012 to investigate the role of occupational closure in the development of overall wage inequality and in different parts of the wage distribution. Most research on occupational closure uses cross-sectional data, although wage setting is a dynamic process with power relations that likely shift over time with economic conditions. Longitudinal data reveal whether these institutions have an active or passive role in wage development: do these institutions simply maintain higher average wage levels, or do they generate continuously accumulating wage benefits?

\section{The Norwegian context}

The Norwegian labor market, similar to other Nordic countries' labor markets, is characterized by strong peak organizations and centrally coordinated collective-bargaining systems. Employment rates are comparably high, and union density is high. However, changes have occurred over time. The share of union members in the Norwegian workforce declined from $57 \%$ to $52 \%$ in the period under study (Nergaard et al., 2015). The decline of unionization varies considerably among occupations, potentially affecting the development of overall inequality. In recent years, peak associations for professional

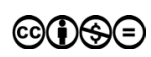


labor have pushed for-and partly succeeded in-shifting from centralized wage bargaining to local and individual-level wage bargaining. In other words, individualization, to some extent, is replacing solidarity in wage formation in higher-paying occupations. Even so, Norway still has a relatively strong collective-bargaining system with centralized negotiation. All public-sector employees and $75 \%$ of private-sector employees are covered by collective agreements. Norwegian unions form at the occupational level, especially among paraprofessional and professional occupations. A central element of the bargaining system is thus inter-union bargaining, as unions compete for the distribution of pay increases, and several unions can represent occupational interests (Fennefoss \& Høgsnes, 2008).

Another important feature of Norwegian culture and society is the strong egalitarian tradition favoring small wage differences. Norwegian culture has been described as putting a strong emphasis on equality defined as sameness (Gullestad, 1992), and the Norwegian labor market is characterized by a relatively compressed wage structure (Barth et al., 2003). Even in comparisons to other Scandinavian countries, Norwegians consider their own country to be highly egalitarian (Hjellbrekke \& Korsnes, 2014: 56).

During 2003 to 2012, Norway was characterized by strong economic expansion and was not as affected by the financial crisis (2008-2009) as many other European and western countries (Dale-Olsen \& Østbakken, 2016). Instead, Norway has had real wage growth and low unemployment levels throughout the period. These trends imply that more rents can be extracted during prosperous times than in meagre times, perhaps more obvious in relation to unions, which have a formalized role in wage bargaining, than in credentialization and licensure. Alternatively, a general undersupply of labor might support high labor prices overall and prevent the growth of inequality.

Although relatively low, wage inequalities in Norway are still substantial. Mastekaasa (2011) documents low but rising inequality in Norway from 1975 to 2004, entirely within the upper range of the wage distribution. This development continues into the next decade, through 2012 (Dale-Olsen \& Østbakken, 2016). Dale-Olsen and Østbakken (2016) find that the increasing income difference in the top end of the income distribution is more marked when they analyze the broadest income measure (which also includes income from capital). They also find more inequality among men than among women. Mastekaasa's (2011) analyses reveal stable patterns of wage inequality between groups with different educational levels in Norway. The observed increase in overall inequality, thus, stems from rising within-group wage inequality among those with tertiary education. Mastekaasa (2011) hypothesize that normative pressure for equality in Norway concentrates on maintaining small between-group differences, so within-group variations in the top ends of the wage and education hierarchies escape public attention. Mastekaasa (2011) attributes the lack of increased differences in the lower end of the wage distribution to the country's collective-bargaining system. More recently, Jordfald and Nymoen (2016) show that wage growth in the lower wage decile over the past decade lags behind the rest of the workforce. Workers in the lower wage decile are typically young, labor migrants with a low probability of union membership. Unskilled occupations in sales and services are overrepresented in the lower wage segment. Therefore, we expect to find increasing inequality both in the upper and lower ends of the wage distribution. 


\section{Occupational closure and wage inequalities}

Wage inequality might be due to several factors. Conventional labor market economics (human capital theory) argues that wages are set according to workers' marginal productivity. A different perspective on (the increasing variations in) wage returns emphasizes different forms of rent seeking (Sørensen, 1998; Stiglitz, 2012). In the labor market, occupational closure is a major form of rent seeking.

Occupational closure theory argues that occupations are the central unit of social stratification because they constitute the basis for organizing economic group interests (e.g., increasing wages and improving working conditions). Occupations include people with similar education or training, similar work tasks and employment conditions, similar social class and life chances, and similar interests (Jonsson et al., 2009; Williams, 2013, p. 843). Closure theory builds on Weber's (1978, pp. 339-355) account of economic relationships among organized groups. He addresses the monopolization of resources and closure against competition from outsiders, citing the medieval guilds as typical examples of such behavior (Weber, 1978). Modern-day professions can be seen as the successors of the guilds because the professions successfully restrict full competition (Stiglitz, 2012, p. 54). The professions argue that their aim is to protect consumers and clients by maintaining standards. This might be true, but even so, entry restrictions (e.g., limiting places at medical schools and immigration of trained personnel) also result in higher wage levels. Bol and Weeden (2015, p. 355) accordingly define closure as 'legal and normative barriers [that] restrict the supply of labor to a labor market position and protect its incumbents from external competition'.

Efficient closure devices, in other words, generate monopoly rents, or a wage surplus that exceeds the wages that could be collected in a truly competitive market (Sørensen, 2000). Weeden (2002) identifies four strategies that occupations use to increase wages: (1) reducing the labor supply; (2) signaling higher quality of service; (3) channeling demand; and (4) increasing demand. This study examines three institutions of occupational closure: licensure (which reduces supply, signal quality, and channel demand); unionization (which reduces labor supply); and credentialization (which reduces supply and signal quality).

\section{Licensure}

Laws regulate access to licensed occupations, making unauthorized practice of that work illegal. Licensure is a true monopoly: only those with licenses have the right to perform specific occupational tasks. Licensure and average wages have a positive correlation so that licensed occupations tend to pay higher wages (Bol \& Weeden, 2015; Humphries et al., 2010; Weeden, 2002). Licensure has stronger effect among the higher tiers of the wage distribution, giving greater benefits to already highly paid individuals (Weeden 2002; Bol \& Drange, 2016; Weeden, 2002). At the same time, licensure can reduce internal variability in wages because these occupations are internally less skillsensitive, resulting in wages being paid according to position, not productivity (Moore, 1981). The consumers feel confident that every doctor knows what he or she is doing, and the license serves as a state warranted guarantee against lemons in the market. Previous research also shows that licensure equalizes internal wage inequality (Bol \& 
Drange, 2016). Thus, we expect to find an equalizing effect of licensure internally within occupations (reducing within-occupation differences) and the opposite between occupations, especially at the top end of the wage distribution.

\section{Unionization}

Unionization raises mean wages and compresses wage dispersion, as shown by many studies (Rosenfeld, 2014; Wallerstein, 1999). According to Weeden (2002), unionization works through the mechanism of restricting supply. Unions do not monopolize occupations as licensure does, but through unions, employees can impose collective wage demands on employers. A company with collective agreements has no alternative cheaper labor to unionized workers. Generally, unions reduce wage inequality by negotiating at the group level, which equalizes within-group pay levels and increases the bargaining power among low-paid workers. Card (1998, p. 19), for example, finds that rising unionism is 'a significant force in forestalling rising wage inequality' in the US public sector.

According to closure theory, unions affect occupational wage levels only if there is a correlation between the occupation and the results achieved by the union, and in Norway, this is the case. We thus expect to find that unionization has an equalizing effect internally within occupations (reducing within-occupation differences) and may decrease between-occupation differences, especially at the bottom end of the wage distribution. The recent decline in the strength of Norwegian unions, as seen, might reduce the expected equalizing effect ${ }^{2}$, especially at the top end of the wage distribution.

\section{Credentialization}

Credentialization implies that educational credentials are used as a source of occupational closure, reserving positions for those with the right amount and type of education (Collins, 1979). Clearly then, this device is mostly found in professional and associate professional occupations, although some craft and trade occupations also have selective educational standards. Credentialization increases mean wages by restricting supply and signaling quality of service but does not channel demand to the occupation as licensure does (Weeden, 2002), that is, it is not a true monopoly.

The expected contributions of credentialization to overall, top-end, bottom-end, within-occupation, and between-occupation wage inequalities are not as clear-cut as the other two closure institutions. Credentialization might have correlations with higher wages, so if the number of credentialized groups or the degree of credentialization increases, then credentialization might contribute to greater between-occupation wage inequalities. Whether the more credentialized occupations are able to secure larger shares of wage increase is uncertain.

\section{Occupational closure and between- and within-occupation wage inequalities}

In keeping with previous research, then, we expect that the closure devices will correlate with higher earnings. But what about the correlation with changes in wage inequality? 
Differences between occupations can increase in at least two ways. ${ }^{3}$ First, the size of different occupations might change in different directions and at different rates. If mid-wage groups (e.g., secretaries) decrease in size, and low- and high-wage groups grow bigger, overall wage inequality would increase, even with stable wage differences between the occupations. ${ }^{4}$

Second, the mean wages in different occupations might change (Mouw \& Kalleberg, 2010; Williams, 2013). In this scenario, high-paying occupations get higher wages, and low-paying occupations get lower wages. In sum, two features of the occupational closure institutions are relevant to the present study: their extensiveness and wage effects. If the proportion of workers with licenses increases, and licensure increases wages, the licensure contributes to between-occupation wage differences through a compositional effect. Wages might also rise more rapidly in licensed occupations than nonlicensed occupations due to limited supply (a mean wage effect). Kleiner and Krueger (2010) find that, in the US, levels of licensing are increasing, while union density is falling. Norway presents similar trends, with more regulated occupations (Bol \& Drange, 2016) and slightly declining union density (Nergaard et al., 2015). Both union density and licensure predict higher wages (Bol \& Drange, 2016; Bol \& Weeden, 2015; Humphries et al., 2010; Weeden, 2002). Moreover, the wage premium for licensed occupations is larger among professionals (Weeden, 2002) and higher social classes (Bol \& Drange, 2016), while union density boosts wages at the lower end of the wage distribution (Barth et al., 2003). These trends suggest that licensure and union density have different impacts on the overall distribution of wages.

\section{Data}

We use administrative register data on employment and wages from 2003 to 2012 for all residents of Norway born after 1945. The employment data include information on occupations, working hours, days of employment, and geographical location of workplaces. This dataset is merged with information from other registers on demographic characteristics, education levels, and union membership. Occupational licensure information is drawn from the Norwegian Occupational Regulations Database. ${ }^{5}$

\section{Operationalization of the dependent variable}

The dependent variable is the variance of the logarithm (varlog) of gross annual wages from employment. Wages are consumer price index adjusted to 2013 levels. To reduce the influence of extreme outliers, all observations that exceed 5 million NOK in wages $(0.35 \%$ of observations $)$ are removed. The data do not link wages and employment relationships, so annual wages might be gained from multiple employment relationships. Therefore, the sample is restricted to full-time employees ( $>29$ hours a week) with contracts covering 11 months of the calendar year. This status increases the likelihood that individuals earned the observed annual wages in their primary occupation. Persons who are self-employed, unemployed, or enrolled in labor market measures are excluded. The sample is limited to persons between the ages of 25 and 67 years. The lower age limit eliminates students and apprentices, while the upper age limit is the retirement age.

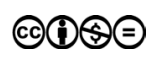


The sample restrictions correspond to those in previous research on wage inequality (Mastekaasa, 2011).

\section{Operationalization of occupations}

The classification structure for occupations used is STYRK, a Norwegian version of the international ISCO-88 code. Occupations are classified by skill level and specialization with four levels of detail. The most aggregated level only specifies skill level, ranging from unskilled to professionals and managers. The second and third levels also include field of work. The fourth level has the highest level of detail and identifies specific occupations (e.g., nurses, electricians, police officers). This level is used in the analyses. Excluded are the military, legislators, and occupations with fewer than 100 observations from 2003 to 2012. The excluded occupations are found among associate professionals, technicians, and the craft- and trades occupations. The analysis includes a final total of 323 occupational groups.

Private-sector employers have reported occupations since 2003. Public-sector employers started using the standardized occupational codes later and earlier reported occupational codes from collective wage agreements. These codes are translated into STYRK codes based on exact matches of job title or matches based on job title, education, and industry. After imputing the codes, occupational information is missing for only $5 \%$ of employees, mostly consultants, officials, and administrative staff. Missing information declines over time and is unlikely to change the general pattern of earnings equality or inequality found in the analyses. A strength of the current research, compared with most previous research on between-occupation wage differences, is the ability to identify the institutions affiliated with rent seeking at the occupational level. Thus, this theoretical and methodological approach constitutes a strong design for determining the impacts of these structural conditions on wage differences.

\section{Independent variables}

The main variables of interest measure different aspects of occupational and social closure, specifically licensure, union density, and credentialization. Licensure is measured at the occupational level as the share of workers within an occupation that hold jobs subject to legal regulation. Some occupations have licensing requirements for all jobs within the occupation (e.g., medicine), while other occupations have legal requirements only for specific jobs (e.g., accounting). Union density measures the share of workers in an occupation who belong to unions. Information on union membership is collected from tax registers. Finally, the credentialization variable measures the extent to which incumbents of an occupation has similar or diverse educational credentials. This is a measure of school-to-work linkage developed by DiPrete et al. (2017: appendix A) that combines information about education level and field of study and how it relates to labor market positions. Occupations whose incumbents have similar levels and types of education have a higher score for this variable than occupations with a wide range of educational levels. Thus, the higher the score, the more closed the occupation is. The analyses also adjust for compositional effects, such as share of female workers and share 
of workers with immigrant origin. Table 1 displays the descriptive statistics for the occupational variables.

Table I Descriptive statistics for occupational-level covariates

\begin{tabular}{lcccccc}
\hline & Licensure & $\begin{array}{c}\text { Union } \\
\text { density }\end{array}$ & $\begin{array}{c}\text { Credent- } \\
\text { ialization }\end{array}$ & $\begin{array}{c}\text { Average } \\
\text { share of } \\
\text { HE }\end{array}$ & $\begin{array}{c}\text { Average } \\
\text { share of } \\
\text { women }\end{array}$ & $\begin{array}{c}\text { Average } \\
\text { share of } \\
\text { immigrants }\end{array}$ \\
\hline Mean & 0.23 & 0.57 & -0.07 & 0.39 & 0.40 & 0.09 \\
Min. & 0 & 0 & -1.58 & 0 & 0 & 0 \\
Max. & 1 & 1 & 1.93 & 1 & 1.00 & 0.61 \\
Std. dev. & 0.39 & 0.25 & 0.71 & 0.34 & 0.30 & 0.08 \\
\hline
\end{tabular}

Note: All years combined; $N=1$ I,528,792. $\mathrm{HE}=$ higher education.

Equally interesting for our analysis of changes over time is to see whether there has been any development in the closure devices during the period in question. Table 2 summarizes the occupational means of the three closure devices for each year.

Table 2 Development in mean occupational closure variables

\begin{tabular}{lccc}
\hline Year & Union density & Licensure & Credentialization \\
\hline 2003 & 0.58 & 0.24 & -0.02 \\
2004 & 0.58 & 0.23 & -0.04 \\
2005 & 0.56 & 0.21 & -0.08 \\
2006 & 0.58 & 0.24 & -0.05 \\
2007 & 0.58 & 0.23 & -0.07 \\
2008 & 0.57 & 0.23 & -0.08 \\
2009 & 0.56 & 0.21 & -0.11 \\
2010 & 0.57 & 0.22 & -0.07 \\
2011 & 0.56 & 0.23 & -0.07 \\
2012 & 0.56 & 0.22 & -0.07 \\
\hline
\end{tabular}

Interestingly, Table 2 summarizes a very stable picture over the 10 years we examine. It may be that there are some more variations on the occupational level (see Nergaard et al., 2015 , on union density), but in overall averages, the stability is striking. This stability gives reason to expect that the possible compositional effect of the occupational closure institutions on changing wage inequality is less likely than the mean wage effects.

\section{Methods}

In the analyses, we will rely on two different methods: (a) growth curve regressions, and (b) unconditional quantile regressions. With the first methods, we are able to decompose 
the total wage inequality into within- and between-occupation wage inequality, and see to what extent both are affected by our measures of occupational closure. With the unconditional quantile regressions, we investigate to what extent our measures of occupational closure explain the change in wage inequality at different points of the wage distribution from 2003 to 2012.

\section{Growth curve regressions}

The variance of log wages is scale invariant and increases in response to wage transfers at the lower end of the wage distribution, making it a suitable measure for studying wage inequality. The most attractive feature of variance of log wages for this research, though, is that it can be decomposed into within- and between-occupation inequality (Allison, 1978).

The analytical approach is based on the framework for studying inequality suggested by Western and Bloome (2009) and similar to that used in previous empirical research on this topic (Mouw \& Kalleberg, 2010; Williams, 2013). The analysis consists of three steps. First, descriptive analysis decomposes the development of wage inequality into between- and within-occupation inequality for 2003-2012 separately for men and women. The variance in wages $(\mathrm{V})$ is the sum of the variance in wages between occupations (B) and within occupations (W). This relationship is expressed in equation (1).

$$
\begin{aligned}
& V=B+W \\
& V=\sum_{j} s_{j} r_{j}^{2}+\sum_{j} s_{j} \sigma_{j}^{2}
\end{aligned}
$$

The between-occupation wage component is the product of the share of employees belonging to the occupation $j$ denoted by $\mathrm{s}_{\mathrm{j}}$ and the square of the deviation of the occupational mean wage from the grand mean $r_{j}^{2}=\left(\mu_{j}-\bar{\mu}\right)$. The within-occupation component is the product of the share of the employees belonging to occupation $j$ and the variance of wages within that occupation $j$, denoted by $\sigma_{j}^{2}$.

Next, the extent to which the rise in inequality can be attributed to changes in occupational composition (e.g., between-occupation changes: occupations sizes increase or decrease, changes in the mean wage effect) and within-occupation effects is analyzed. In line with previous research, the models are estimated separately for men and women due to the gender-segregated occupational structure. Changes in the log variance of wages are the deviation between two points in time (time $t_{0}$ and time $t_{1}$ ), as specified in equation 2 .

$$
V_{t 1}-V_{t 0}=\left(B_{t 1}-B_{t 0}\right)+\left(W_{t 1}-W_{t 0}\right)
$$

Changes in between-occupation wages arise from changes in occupation size and the mean wage effect; therefore, the first part of equation 3 consists of, first, the compositional effect and, second, the wage effect.

$$
B_{t 1}-B_{t 0}=\sum\left(s_{j t 1}-s_{j t 0}\right) r_{j t 1}^{2}+\sum s_{j t 0}\left(r_{j t 1}^{2}-r_{j t 0}^{2}\right)
$$


Similarly, changes in within-occupation wages are also due to changes in the compositional effect and the variance in wages.

$$
W_{t 1}-W_{t 0}=\sum\left(s_{j t 1}-s_{j t 0}\right) \sigma_{j t 1}^{2}+\sum s_{j t 0}\left(\sigma_{j t 1}^{2}-\sigma_{j t 0}^{2}\right)
$$

Equation 2 then can be rearranged into three components, where the changes in overall $\log$ variance of wages are attributable to changes in mean occupational wages $\Delta \mathrm{B}$, changes in within-occupation wages $\Delta \mathrm{W}$, and a composition effect $\Delta \mathrm{C}$ :

$$
V_{t 1}-V_{t 0}=\Delta B+\Delta W+\Delta C
$$

Equations 6-8 show the calculations for the three components from equation 5.

$$
\begin{gathered}
\Delta B=\sum s_{j t 0}\left(r_{j t 1}^{2}-r_{j t 0}^{2}\right) \\
\Delta W=\sum s_{j t 0}\left(\sigma_{j t 1}^{2}-\sigma_{j t 0}^{2}\right) \\
\Delta C=\sum\left(s_{i t 1}-s_{j t 0}\right)\left(r_{j t 1}^{2}+\sigma_{j t 1}^{2}\right)
\end{gathered}
$$

Third, multivariate models are estimated to test whether licensure, union density, and credentialization can explain some of between- and within-occupation wage inequality. The estimation of multivariate models combines the approaches of Mouw and Kalleberg (2010) using individual-level data and Williams (2013, pp. 845-846) using occupational-level data. A standard regression model of mean log wages is first estimated as a function of both individual-level covariates and occupational fixed-effects (eq. 9). This is done for the 2003-2012 period to determine how much individual-level characteristics explain between- and within-occupation wage inequality.

$$
\ln w_{\text {age }} e_{i j}=\beta_{1} X_{i j}+\alpha_{j} O c c_{i}^{j}+\varepsilon_{i j}
$$

$\ln w_{a g e}$ is the $\log$ of the wages for person $i$ in occupation $j . \mathrm{X}$ is a vector of individual covariates that include eight dummy variables for education level, gender, and age, as well as the interaction between gender and age and gender and education level. $\alpha_{j}$ is the occupational fixed-effects, and $\varepsilon_{i j}$ is the error term. The model is estimated as a fixedeffect regression with individuals nested in occupations. The post-estimation tools are used to extract from the analysis the occupational fixed effects, which now measure the mean occupational wages adjusted for compositional effects.

Next, the squared residuals from equation $9, \varepsilon_{i j}$, are used in the model for the variance. Again, the variance is estimated with individual-level covariates and occupational fixed effects simultaneously.

$$
\log \sigma_{i j}^{2}=\beta_{1} X_{i j}+\gamma_{j} O c c_{i}^{j}+\omega_{i j}
$$

$\mathrm{X}$ is a vector containing the same individual-level covariates as equation 9 because gender, education, and age also affect the variance. This model is also estimated as a 
fixed-effects regression, and the occupational level effects are recovered, as in equation 9.

The analyses in equations 9 and 10 are repeated for each year of data. This new dataset has a two-level structure with repeated observations nested within occupations. The data consist of 323 occupations observed for a maximum of 10 years, creating an unbalanced panel with 3168 observations.

Next, the mean $\log$ wages fixed-effects $\alpha_{j}$ and the within-occupation variance fixed-effects $\gamma_{j}$ estimated in equations 9 and 10 are used as the dependent variables for the multivariate growth-curve models. Growth-curve models are specified to serve the research interest in the development of wage inequality. The model estimation is a two-level model with occupation-years nested in occupations. The regressions uses the occupational level data from the first-stage regressions 9 and 10. The modeling follows Kim and Sakamoto (2008, pp. 136-137). The model for between-occupation inequality is as follows:

$$
\begin{gathered}
\alpha_{j t}=\beta_{0}+\beta_{1} \text { Year }_{j t}+\varepsilon_{j t} \\
\alpha_{j t}=\beta_{0}+\beta_{1} \text { Year }_{j t}+\beta_{2} x_{t j}+\beta_{3} \bar{x}_{j}+\beta_{4}\left(\text { Year }_{j t} * \bar{x}_{i}\right)+\theta_{1} \bar{w}_{j}+\theta_{2} w_{j t}+\varepsilon_{j t}
\end{gathered}
$$

The model for within-occupation inequality is as follows:

$$
\begin{gathered}
\gamma_{j t}=\beta_{0}+\beta_{1} \text { Year }_{j t}+\varepsilon_{j t} \\
\gamma_{j t}=\beta_{0}+\beta_{1} \text { Year }_{j t}+\beta_{2} x_{t j}+\beta_{3} \bar{x}_{j}+\beta_{4}\left(\text { Year }_{j t} * \bar{x}_{j}\right)+\theta_{1} \bar{w}_{j}+\theta_{2} w_{j t}+\varepsilon_{j t}
\end{gathered}
$$

The baseline models (eq. 11 and eq. 13) contain only the intercept $\beta_{0}$, a yearly growth curve $\beta_{1}$ and the error term $\varepsilon_{\mathrm{jt}}$, where $\varepsilon_{\mathrm{jt}}=\left(\xi_{\mathrm{j}}+\varphi_{\mathrm{jt}}\right)$. $\xi_{\mathrm{j}}$ is the occupational-specific error term and $\varphi_{\mathrm{jt}}$ is an idiosyncratic error term.

The next set of models (eq. 12 and eq. 14) has five additional estimators: $\beta_{2}, \beta_{3}$, and $\beta_{4}$ and controls $\theta_{1}$ and $\theta_{2}$. The coefficient $\beta_{2}$ gives the effect of the occupational specific closure measure, $\mathrm{x}_{\mathrm{it}}$, (proportion of licensed workers, proportion of union organized workers, and linkage strength), and shows whether changes in the occupational closure variables are associated with changes in the mean occupational wages (eq. 12) or withinoccupational variances (eq. 14). Coefficient $\beta_{3}$ gives the effect of the occupational average of each closure device, $\bar{x}_{j}$, and shows variation in wage inequality associated with the closure devices. Coefficient $\beta_{4}$ is the interaction effect between the occupational average and year, and predicts whether the changes to returns in occupational closure have increased or decreased over time, net of the effects associated with change in strength of occupational closure. Hence, an increase in the returns from licensure during the period studied results in a positive $\beta_{4}$-estimator. An increase in the share of licensed workers might also lead to higher wage inequality, as observed by the $\beta_{2}$-estimator.

The vectors $\mathrm{w}_{\mathrm{jt}}$ and $\bar{w}_{i}$ contain the control variables that are the proportion of females and immigrants in the occupation and the average composition of females and immigrants in the occupation. Thus, $\theta_{1}$ predict the change in wage inequality associated with changes in the proportion of females and immigrants, net of the average 
composition of females and immigrants in the occupations given by $\theta_{2}$.

A consequence of the two-step method is that the components of the closure variables that correlate with individual characteristics in the first step is attributed to the individual variables, which would produce more conservative estimates for the closure variables. This is not problematic, as closure should be beneficiary to all workers in the occupation, irrespective of education level etc.

\section{Unconditional quantile regression}

We also examine the effects on changes in wage inequality from the three closure characteristics studied (licensure, unionization, and credentialization). Unconditional quantile regressions (Firpo et al., 2009) are used to assess the influence of these three occupational institutions at different points of the wage distribution. Unconditional quantile regressions involves calculating a recentred influence function (RIF) for each quantile of interest, which we will then use as dependent variables in linear regression. In contrast to conditional quantile regression, RIFs have an unconditional interpretation and are therefore not based on other covariates in the model. This means that one is able to decompose changes in wage differentials between two time points into a composition effect (i.e., changes in the levels of occupational closure) and a wage effect (i.e., changes in the wages attached to occupational closure) using a Oaxaca-Blinder type decomposition. Wage effects refer to the higher returns under a closure institution for some groups in the wage distribution. Closure institutions might also effect changes in aggregate inequality when the share of workers within an institution differs across the distribution. Licensure, for example, might raise wages either because the returns from licensure are higher for high-earnings workers (wage structure effects) or because licensed occupations have more high-earning workers (composition effects).

In line with earlier studies, we use a counterfactual reweighting procedure (Fortin et al., 2011). Composition effects are the effects obtained from a decomposition comparing 2003 to the reweighted 2003 (weighted to 2012 based on all variables). Wage effects are the effects obtained from a decomposition comparing 2012 with the reweighted 2003. The error from the reweighting procedure is then the composition effect from this latter decomposition.

We examine the change in wages at three points in the distribution: the 10th, the 50th, and the 90th percentiles. This will indicate how closure has affected changes in wages at different points in the distribution, and therefore wage inequality.

\section{Descriptive results}

\section{Trends in wage inequality for men}

Figure 1 presents the development in wage inequality from 2003 to 2012 among fulltime employed men. Inequality increases in this period, as evident from the rising slopes from 2003 to 2012. The overall level of wage inequality, represented by the solid line, rises by $22 \%$ [(0.169-0.138)/0.138]. Although this is an increase, it should be noted that the wage inequality in Norway is comparatively quite modest at the starting 
Figure I: Wage inequality (overall, within-, and between-occupation) 2003-2012, full-time employed men.

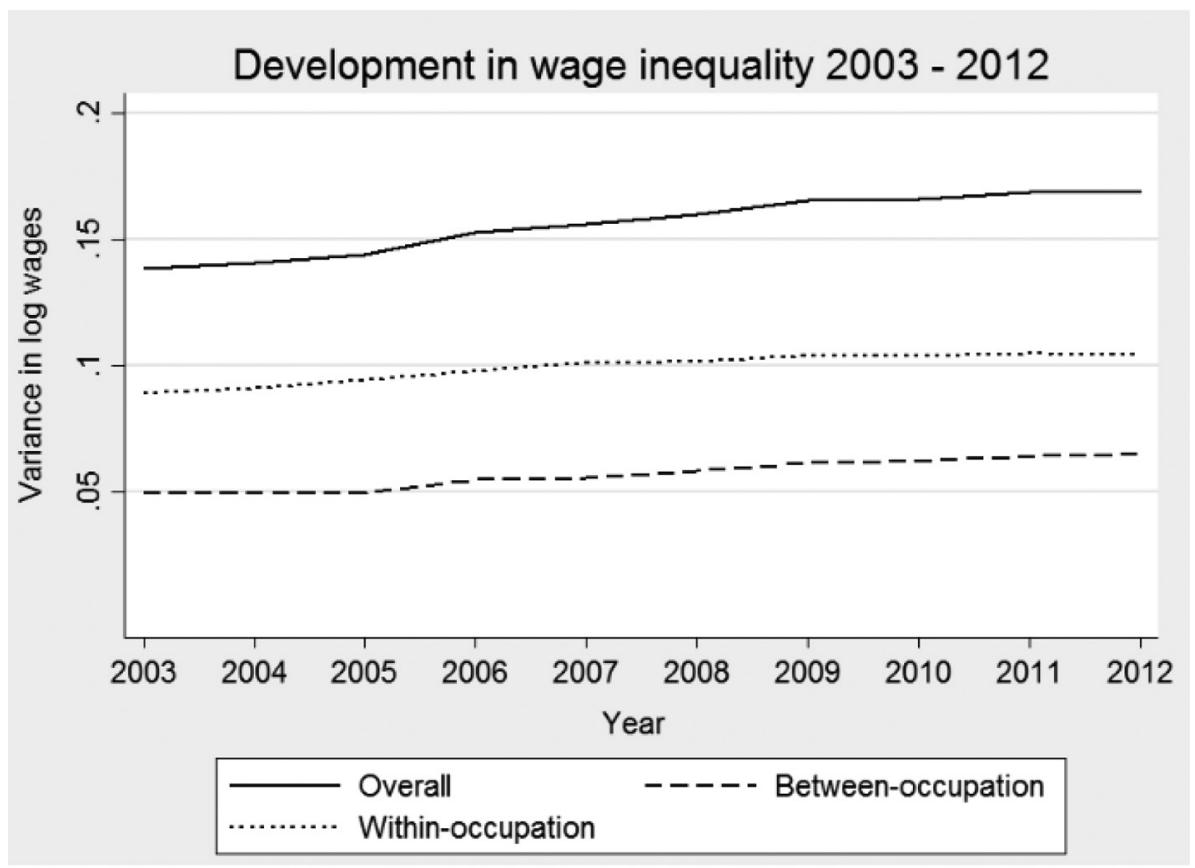

point in 2003. The variance in log wages for Norway in 2003 is less than one-third of the variance in log wages for the US (Mouw \& Kalleberg, 2010, p. 412) and the UK (Williams, 2013, p. 844).

In addition to the general trend in the variance in log wages, Figure 1 shows the decomposition of within- and between-occupation variance. Within-occupation variance is clearly more important than between-occupation variance to the overall variance in wages. Approximately two-thirds of the total variance in wages is between workers within the same occupational categories, and one-third between the average earnings of different occupations.

Figure 1 also reports the changes in the two types of wage inequality. When looking at the figure, the slope for the between-occupation wage inequality seems steeper. This steep slope is even more visible in Figure 2, which shows changes in the relative contributions of within- and between-occupation wage inequality. The increase in betweenoccupational inequality is stronger than the increase in within-occupation inequality during the period studied. From 2003 to 2012, the variance in mean occupational wages increases by $31 \%$ [ $(0.065-0.049) / 0.049]$, and the variance in within-occupation wages by $17 \%$ [(0.104-0.089)/0.089].

Figure 2 indicates the proportion of overall inequality explained by occupations. The variance in between-occupational wages becomes more important to explaining overall variance in wages during the 10 years studied, as evidenced by the narrowing gap between the within- and between occupation slopes. Between-occupational inequality's 
Figure 2: Between- and within-occupation inequality as a proportion of overall inequality, full-time employed men.

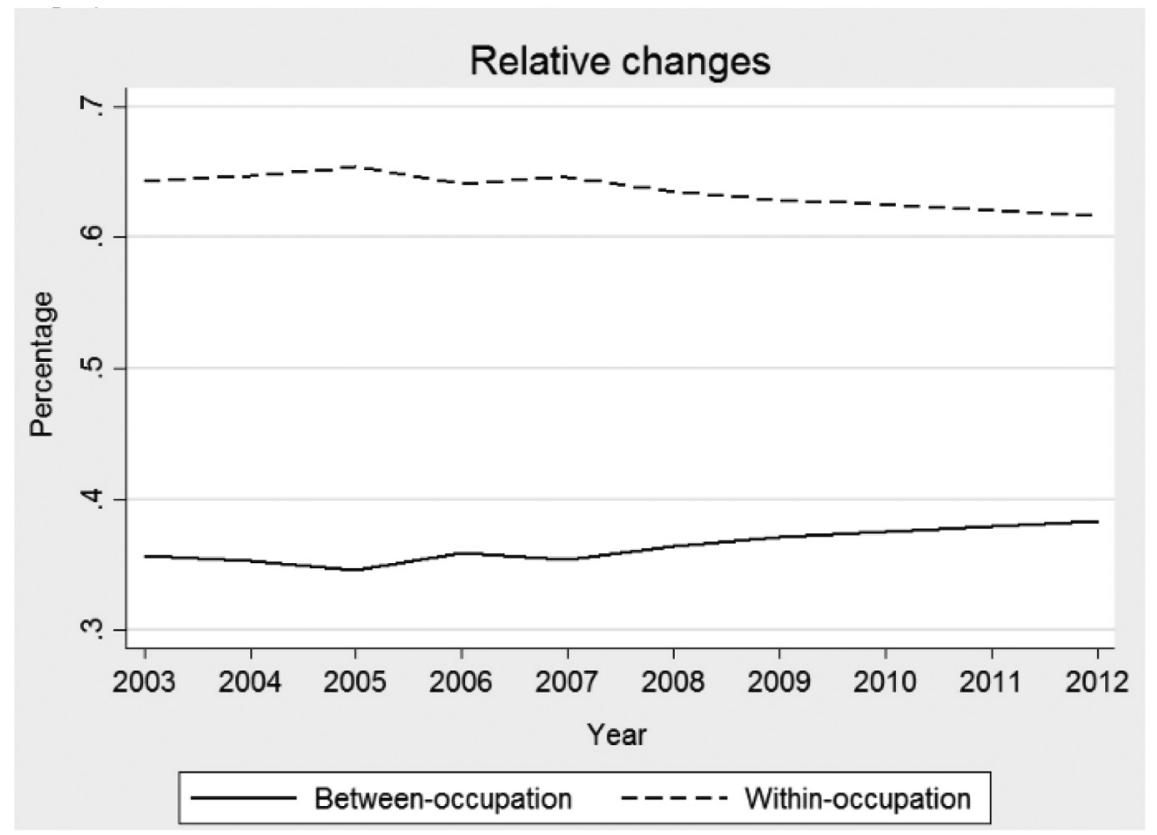

Table 3 Decomposition of inequality for full-time employed men

\begin{tabular}{ccccc}
\hline & $\boldsymbol{V}_{\mathbf{2 0 1 2}}-\boldsymbol{V}_{\mathbf{2 0 0 3}}$ & $\Delta \mathbf{B}$ & $\Delta \mathbf{W}$ & $\Delta \mathbf{C}$ \\
\hline $2003-2012$ & 0.0308 & 0.0136 & 0.0128 & 0.0043 \\
\hline
\end{tabular}

explanatory power for overall inequality increases by a modest 2.5 percentage points. Wage differences between workers in the same occupations are still much more important than the average wage differences between occupations.

In the second stage of analysis, the changes in overall inequality are further decomposed into changes in mean occupational wages, within-occupation wages, and composition effects. The variance of log wages increases by 0.0308 , of which changes in mean occupational wages account for $44 \%(0.0136 / 0.0308)$, changes in the variance of within-occupation wages $42 \%(0.0128 / 0.0308)$, and composition effects $14 \%$ $(0.0043 / 0.0308)$. Thus, changes in wages between occupations and greater variation in wages within occupations equally contribute to rising wage inequality levels in Norway, while the changes to composition explain only a small share.

\section{Trends in wage inequality for women}

Figure 3 presents the development of wage inequality from 2003 to 2012 among fulltime employed women. The overall level of wage inequality, represented by the solid 
Figure 3: Wage inequality (overall, within-, and between-occupation), 2003-2012, full-time employed women.

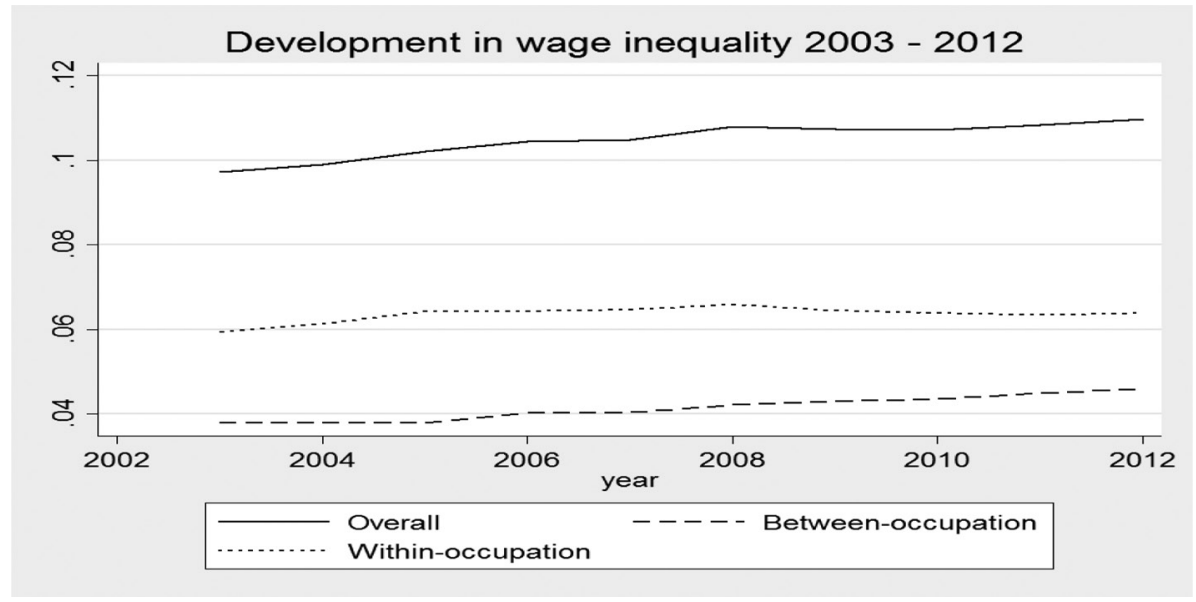

Figure 4: Between- and within-occupation inequality as a proportion of overall inequality, full-time employed women.

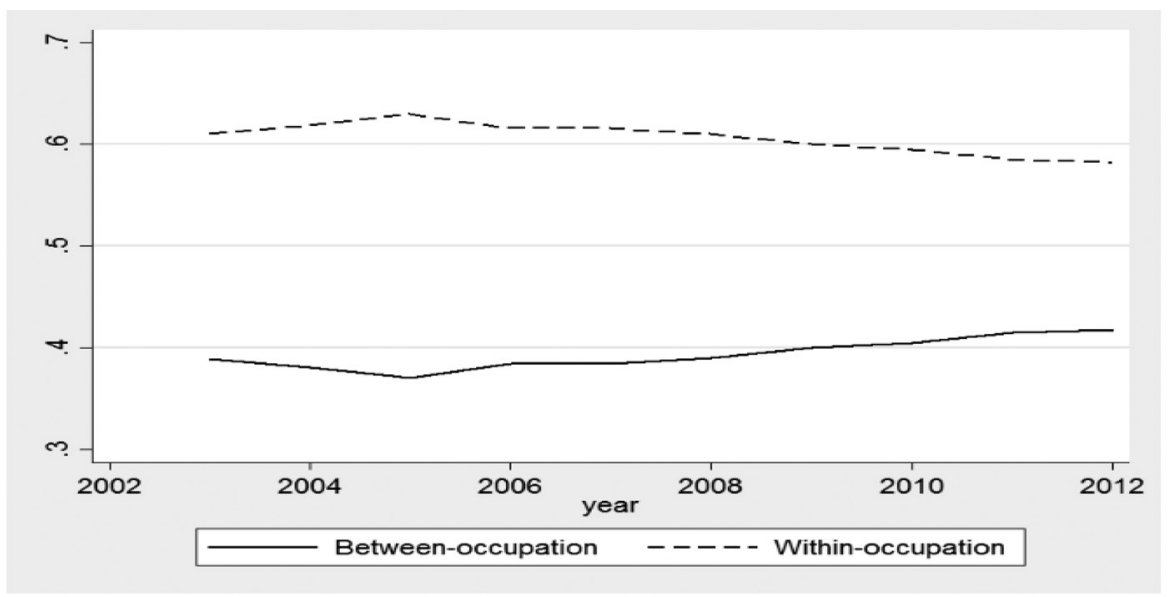

line, increases by $12 \%$ [(0.109-0.097)/0.097], the variance in mean occupational wages by $21 \%$ [(0.046-0.038)/0.038], and the variance in wages within occupations by $8 \%$ $[(0.064-0.059) / 0.059]$. Figure 4 presents the proportion of overall inequality among women explained by occupations. The pattern is the same as for men, but the convergence of within- and between-occupational wages is more pronounced. The explanatory power of between-occupational inequality for overall inequality increases by 2.3 percentage points.

The analysis shows that changes in mean occupational wages account for $54 \%$ $(0.0068 / 0.0125)$ of the changes in overall variance of $\log$ wages, changes in the 
Table 4 Decomposition of inequality for full-time employed women

\begin{tabular}{ccccc}
\hline & $\boldsymbol{V}_{\mathbf{2 0 1 2}}-\boldsymbol{V}_{\mathbf{2 0 0 3}}$ & $\Delta \mathbf{B}$ & $\Delta \mathbf{W}$ & $\Delta \mathbf{C}$ \\
\hline $2003-2012$ & 0.0125 & 0.0068 & 0.0034 & 0.0023 \\
\hline
\end{tabular}

variance of within-occupation wages $27 \%(0.0034 / 0.0125)$, and composition effects $18 \%(0.0043 / 0.0125)$. Compared with the results for men, a larger share of the rise in inequality among women lies between occupations or in the composition of the occupational structure. However, the main conclusion again is that both within- and between-occupation wage inequalities contribute equally to the modest change in Norwegian wage inequality, in this case for women.

\section{Effects of occupational closure}

\section{Between-occupational wage inequality}

The second stage of analysis investigates whether between- and within-occupation wage inequality is related to union density, licensure, and credentialization. Can these occupational institutions explain the changes in wage inequality in Norway?

Occupational closure can affect changes in mean occupational wages through a change in the proportion of workers in closed occupations, or by a change in the importance of the closure device for wage setting. The wage response to proportional change is given by the coefficients for licensure, union density, and credentialization. The interaction between year and the occupational average of each closure device tells whether the device has become more or less important for wage setting, net of changes in the proportion of workers covered by the device.

The analyses in Table 5 display wage responses to the closure devices separately (model 2 - model 4) and adjusted for the other devices (model 5). Thus, this model shows the unique contribution of each device, net of the wage effect of the other devices. The final model includes controls for gender and immigrant composition (model 6).

Table 5 presents the results from the multivariate growth models for the development of $\log$ mean wages. Model 1 only includes the time trend and shows that mean occupational wages increase by $2.3 \%$ per year, supporting the results of the descriptive models. The next model shows the results of licensure. Both the occupational-specific mean and the occupational-specific changes in licensure are positive, but insignificant. The interaction term shows that wages in licensed occupations increase by $0.4 \%$ per year, net of changes in the proportion of licensed workers, yielding a total wage increase of $4.0 \%$ for licensed occupations over the 10 years studied. Because the association between licensure and wages might be different in high- or low-paying occupations, the wage response to changes in proportion of licensed workers and the change in the importance of licensure were tested with interactions for high wage and low wage occupations (defined as occupations with mean wages 1 std. above or below the mean wage). The results revealed that high wage occupations received a larger wage premium over time and larger wage premiums from compositional change (results not shown).

The third model shows the results for union density. The occupational-specific mean is negative and significant. A negative coefficient indicates that union density reduces 
Table 5 Between-occupational wage regression

\begin{tabular}{|c|c|c|c|c|c|c|}
\hline & $\begin{array}{c}\text { Model } 1 \\
\text { b/(se) }\end{array}$ & $\begin{array}{c}\text { Model } 2 \\
\text { b/(se) }\end{array}$ & $\begin{array}{c}\text { Model } 3 \\
\text { b/(se) }\end{array}$ & $\begin{array}{c}\text { Model } 4 \\
\text { b/(se) }\end{array}$ & $\begin{array}{c}\text { Model } 5 \\
\text { b/(se) }\end{array}$ & $\begin{array}{l}\text { Model } 6 \\
\text { b/(se) }\end{array}$ \\
\hline \multirow[t]{2}{*}{ Year } & $0.023^{* * *}$ & $0.022 * * *$ & $0.021^{* * *}$ & $0.023^{* * *}$ & 0.022 ***** & 0.025 **** \\
\hline & 0.000 & 0.000 & 0.001 & 0.000 & 0.001 & 0.001 \\
\hline \multirow[t]{2}{*}{ OA licensure } & & 0.039 & & & 0.050 & 0.026 \\
\hline & & 0.036 & & & 0.039 & 0.035 \\
\hline \multirow[t]{2}{*}{ Licensure } & & 0.010 & & & -0.016 & -0.020 \\
\hline & & 0.013 & & & 0.012 & 0.012 \\
\hline \multirow[t]{2}{*}{ Year* OA licensure } & & $0.004 * * *$ & & & $0.002 * *$ & 0.001 \\
\hline & & 0.001 & & & 0.001 & 0.001 \\
\hline \multirow[t]{2}{*}{ OA union density } & & & $-0.105 *$ & & $-0.126 *$ & $-0.09 \mid *$ \\
\hline & & & 0.046 & & 0.051 & 0.045 \\
\hline \multirow[t]{2}{*}{ Union density } & & & $0.155^{* * * *}$ & & $0.155 * * * *$ & 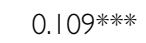 \\
\hline & & & 0.014 & & 0.014 & 0.014 \\
\hline \multirow{2}{*}{$\begin{array}{l}\text { Year* OA union } \\
\text { density }\end{array}$} & & & & & & م000 \\
\hline & & & 0.001 & & 0.001 & 0.001 \\
\hline \multirow[t]{2}{*}{ OA credentialization } & & & & $0.07 \mid$ 米米 & $0.064 * *$ & $0.060 * * * *$ \\
\hline & & & & 0.018 & 0.020 & 0.018 \\
\hline \multirow[t]{2}{*}{ Credentialization } & & & & $-0.05 \mid$ |*** & $-0.052 * * *$ & -0.040 ***** \\
\hline & & & & 0.008 & 0.008 & 0.008 \\
\hline \multirow{3}{*}{$\begin{array}{l}\text { Year* Credentializa- } \\
\text { tion }\end{array}$} & & & & & & \\
\hline & & & & $0.002 * * * * *$ & $0.00 \mid * * * *$ & $0.002 * * * *$ \\
\hline & & & & 0.000 & 0.000 & 0.000 \\
\hline \multirow[t]{2}{*}{ Proportion females } & & & & & & -0.020 \\
\hline & & & & & & 0.024 \\
\hline \multirow{3}{*}{$\begin{array}{l}\text { OA proportion } \\
\text { females }\end{array}$} & & & & & & \\
\hline & & & & & & $-0.158^{* * * *}$ \\
\hline & & & & & & 0.043 \\
\hline \multirow{2}{*}{$\begin{array}{l}\text { Proportion immi- } \\
\text { grants }\end{array}$} & & & & & & -0237 ***** \\
\hline & & & & & & 0.020 \\
\hline \multirow{3}{*}{$\begin{array}{l}\text { OA proportion } \\
\text { immigrants }\end{array}$} & & & & & & \\
\hline & & & & & & $-0.757 * * * *$ \\
\hline & & & & & & 0.120 \\
\hline \multirow[t]{2}{*}{ Cons } & $12.655^{* * *}$ & $12.648 * * *$ & $12.624 * * *$ & $12.653^{* * *}$ & $12.631 * * *$ & $12.791^{* * *}$ \\
\hline & 0.011 & 0.012 & 0.027 & 0.011 & 0.028 & 0.030 \\
\hline Level 2 var(cons) & $0.039 * * *$ & $0.038 * * *$ & $0.039 * * *$ & $0.038 * * * *$ & $0.038 * * *$ & $0.029 * * *$ \\
\hline Level I var(cons) & 0.00 I***** & 0.00 I***** & $0.001 * * * *$ & 0.001 ****** & $0.001 * * * *$ & 0.00 I***** \\
\hline
\end{tabular}

Multivariate growth models for log mean occupational wages (a). Fulltime employed women and men aged 25-67 years.

$\mathrm{OA}=$ occupational average, $\sim p \leq 0.10, * p \leq 0.05, * * * \leq 0.01$, **** $p \leq 0.001, N=3110, n=11,528,792$ 
between-occupational wage inequality. The coefficient for change in proportion of union members $\beta 2$ is positive and significant. If union density rises by $100 \%$, the mean wage increases by $14.4 \%$, and vice versa, the mean wage decreases with declining union density. The net effect of union density across time is positive, so the mean wages of unionized occupations increased by $5.0 \%$ over the 10 years studied. Again, the association between union density and wages might be different in high- or low-paying occupations. The interactions for high wage and low wage occupations revealed that in high wage occupations, wages increased with rising union density and the return to union density also increased, net of proportional change. In low wage occupations, an increase in the proportion of unionized workers gave a smaller wage premium and lower returns to union density, compared with higher paid occupations (results not shown).

Model 4 shows the results for credentialization. The occupational-specific mean is positive and significant and shows that occupations with highly selective educational standards pay higher wages. A one-point increase in the log linkage measure produces $6.9 \%$ higher wages. The coefficient for change in an occupation's credentialization measure $\beta 2$ is negative and significant, indicating that the mean wage decreases by $5.0 \%$ for occupations that become more strongly linked to specific educations. Over the 10 years, the returns for credentialization, net of change in the strength of education-tooccupation linkage, also increase slightly, producing $1.0 \%$ higher wages by 2012 . There is an additional premium to high wage occupations in response to changes in linkage strength and in the returns to linkage across time, but among low wage occupations, an additional wage premium is associated with an increase in the strength of credentialization only (results not shown).

The final model shows the results from the jointly specified model. The changes in the coefficients are small, indicating that the effects from the previous model persist, with the exception of the time trend for union density.

The error variances at the bottom of Table 5 show the variance of level 2 errors $\left(\xi_{j}\right)$ and level 1 errors $\left(\varphi_{\mathrm{jt}}\right)$. The error variance at level 2 decreases in model 2-4 compared with the baseline model. This implies that the closure variables are able to explain very little of the variation in mean occupational wages.

\section{Within-occupation wage inequality}

Table 6 presents the results for the models measuring changes in residual variance, or wage variance within occupations. The table set-up is similar to Table 5, with each device presented separately (model 2-4) and adjusted for the other devices (model 5). Model 5 shows the unique contribution of each device, net of the other devices. Model 6 adds control for gender and immigrant composition and compositional change.

The first model shows that the within-occupation wage inequality decreases by $3.0 \%$ from 2003 to 2012 . In the second model, inequality falls by $3.3 \%$ in occupations with higher proportions of licensed incumbents, and wages in licensed occupations show a tendency toward convergence over the 10 years. The associations between licensure and within-occupation wage variance are similar across high and low-paying occupations.

The third model shows that union density largely decreases within-occupation wage variation. Occupations with high union density generally have lower levels of 
Table 6 Within-occupational wage regression

\begin{tabular}{|c|c|c|c|c|c|c|}
\hline & $\begin{array}{c}\text { Model } 1 \\
\text { b/(se) }\end{array}$ & $\begin{array}{c}\text { Model } 2 \\
\text { b/(se) }\end{array}$ & $\begin{array}{l}\text { Model } 3 \\
\text { b/(se) }\end{array}$ & $\begin{array}{c}\text { Model } 4 \\
\text { b/(se) }\end{array}$ & $\begin{array}{c}\text { Model } 5 \\
\text { b/(se) }\end{array}$ & $\begin{array}{c}\text { Model } 6 \\
\text { b/(se) }\end{array}$ \\
\hline \multirow[t]{2}{*}{ Year } & $-0.003 * * *$ & $-0.003 * * * *$ & $-0.00 \mid * *$ & $-0.003 * * * *$ & $-0.001 \sim$ & $-0.002 * * * *$ \\
\hline & 0.000 & 0.000 & 0.000 & 0.000 & 0.000 & 0.000 \\
\hline \multirow[t]{2}{*}{ OA licensure } & & 0.000 & & & $0.04 I^{*}$ & $0.04 I^{*}$ \\
\hline & & 0.019 & & & 0.018 & 0.019 \\
\hline \multirow[t]{2}{*}{ Licensure } & & $-0.035^{* * * * *}$ & & & $-0.024 *$ & $-0.023 *$ \\
\hline & & 0.009 & & & 0.009 & 0.009 \\
\hline \multirow[t]{2}{*}{ Year* OA licensure } & & -0.001 & & & -0.000 & 0.000 \\
\hline & & 0.000 & & & 0.001 & 0.001 \\
\hline \multirow[t]{2}{*}{ OA union density } & & & -0.079 ***** & & $-0.074 * *$ & 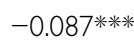 \\
\hline & & & 0.022 & & 0.024 & 0.024 \\
\hline \multirow[t]{2}{*}{ Union density } & & & $-0.082 * * * *$ & & $-0.078 * * * *$ & -0.063 ***** \\
\hline & & & 0.010 & & 0.011 & 0.011 \\
\hline \multirow[t]{2}{*}{ Year* OA union density } & & & $-0.003 * * * *$ & & $-0.004 * * * *$ & -0.003 ****** \\
\hline & & & 0.001 & & 0.001 & 0.001 \\
\hline \multirow[t]{2}{*}{ OA credentialization } & & & & $-0.023 *$ & -0.004 & 0.002 \\
\hline & & & & 0.010 & 0.010 & 0.010 \\
\hline \multirow[t]{2}{*}{ Credentialization } & & & & $-0.010 \sim$ & $-0.011 *$ & -0.016 *** \\
\hline & & & & 0.006 & 0.006 & 0.006 \\
\hline \multirow[t]{2}{*}{ Year* Credentialization } & & & & -0.000 & $0.001 \sim$ & $0.000 \sim$ \\
\hline & & & & 0.000 & 0.000 & 0.000 \\
\hline \multirow[t]{2}{*}{ Proportion females } & & & & & & 0.017 \\
\hline & & & & & & 0.018 \\
\hline \multirow[t]{2}{*}{ OA proportion females } & & & & & & $-0.048 \sim$ \\
\hline & & & & & & 0.025 \\
\hline \multirow[t]{2}{*}{ Proportion immigrants } & & & & & & $0.08 \mid$ ***** \\
\hline & & & & & & 0.015 \\
\hline \multirow[t]{2}{*}{$\begin{array}{l}\text { OA proportion } \\
\text { immigrants }\end{array}$} & & & & & & -0.004 \\
\hline & & & & & & 0.059 \\
\hline \multirow[t]{2}{*}{ cons } & 0.097米米 & $0.102 * * * *$ & $0.190 * * * *$ & $0.100 * * *$ & $0.183 * * * *$ & $0.188 * * * *$ \\
\hline & 0.005 & 0.006 & 0.012 & 0.005 & 0.012 & 0.015 \\
\hline Level $2 \operatorname{var(cons)~}$ & 0.009***** & 0.009 ***** & 0.007米米米 & $0.008 * * * *$ & 0.007 ****** & 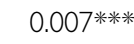 \\
\hline Level I var(cons) & 0.00 I***** & 0.001 ***** & 0.00 I***** & $0.00 \mid * * * *$ & 0.00 I****** & 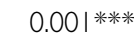 \\
\hline
\end{tabular}

Multivariate growth models for the within-occupation variance in wages $\left(\gamma_{j}\right)$. Full-time employed women and men aged 25-67 years.

$\mathrm{OA}=$ occupational average, $\sim p \leq 0.10, * p \leq 0.05, * * * 100.01$, **** $p \leq 0.00 \mathrm{I}, \mathrm{N}=3 \mathrm{II0}, \mathrm{n}=1 \mathrm{I}, 528,792$ 
wage inequality, and as union density increases in occupations, wage inequality declines. These trends seem logical because occupations with high union membership levels are more likely to have wage bargaining for (groups of) occupational workers. Moreover, the interaction term between union density and time is negative and significant, which implies that the residual wage inequality in unionized occupations was lower in 2012 than 2003. Additional analyses show that the reduction in residual variance in response to higher proportions of unionized workers is less strong in high wage occupations (results not shown).

The fourth model shows that occupations with high shares of workers with similar education have lower residual wage inequality. However, occupations that adopt stricter educational standards do not develop more similar wages, and residual wage dispersion does not decrease in credentialized occupations over the 10 years studies. This result indicates that credentialization reduces within-occupation wage variance (see DiPrete et al., 2017), but the effect does not change over time. The associations between linkage strength and within-occupation wage variance is similar across high and low-paying occupations.

The fifth model shows that occupations with stronger licensing actually have significantly higher wage dispersion after adjusting for union density and credentialization. Still, occupations that increase their share of licensed practitioners have less growth in inequality than occupations that reduce their share of licensed practitioners. The coefficients for union density remain largely unchanged by the joint specification of the model. Credentialized occupations have lower wage inequality, but the estimate is no longer significant. Model 6 adds controls for gender and immigrant composition and compositional change. The addition of the controls does not substantially alter the coefficients of the closure variables.

The error variance at level 2 decreases in model 3-6, compared with the baseline model, but again, the closure variables explain very little of the residual variation in wages.

\section{Unconditional quantile regressions}

The final empirical step more formally investigates to what extent occupational closure affects changes in wage inequality in Norway from 2003 to 2012. Unconditional quantile regressions examine the effects of explanatory variables at different points in the wage distribution, and thus compliments the previous analyses of changes to overall inequality. Differences at various points in the wage distribution from 2003 to 2012 are decomposed into the contributions of the explanatory variables. We assess the extent to which the three forms of occupational closure affect changes in the wage distribution. A benefit of unconditional quantile regression is that it enables analyzing to what extent changes in wages at different points in the wage distribution are due to composition effects or wage structure effects. Table 7 summarizes the results of the RIF regressions and OaxacaBlinder decompositions. We examine the 10th, 50th, and 90th quantiles of log wages. In the table, the total difference refers to the total change in log wages at the mentioned quantiles. This total difference is then decomposed in wage and composition effects.

The first row of Table 7 presents the total difference in mean log annual wages for workers in the 10th, 50th, and 90th percentiles. Here, it is evident that workers 
Table 7 Oaxaca Blinder decomposition using RIF regressions, 2003-2012

\begin{tabular}{lccc}
\hline & I 0th percentile & 50th percentile & 90th percentile \\
\hline Total difference (2012-2003) & 0.308 & 0.376 & 0.430 \\
Composition & -0.009 & 0.027 & 0.055 \\
Age & -0.026 & 0.003 & 0.013 \\
Female & 0.002 & 0.001 & 0.002 \\
Education & 0.013 & 0.022 & 0.041 \\
Licensure & 0.000 & 0.000 & 0.000 \\
Credentialization & 0.001 & 0.000 & 0.000 \\
Unionization & 0.002 & 0.000 & 0.000 \\
Wage structure & 0.317 & 0.350 & 0.375 \\
Constant & 0.250 & 0.144 & 0.270 \\
Age & 0.153 & 0.073 & 0.049 \\
Female & 0.020 & 0.028 & -0.013 \\
Education & -0.235 & 0.055 & 0.000 \\
Licensure & -0.005 & -0.005 & -0.011 \\
Unionization & 0.134 & 0.053 & 0.079 \\
Credentialization & 0.002 & 0.002 & 0.000 \\
\hline
\end{tabular}

throughout the distribution see higher annual wages. As well, the increased wage inequality in Norway is due to more rapidly increasing wages for those at the upper part than the bottom of the wage distribution. In other words, inequality grows because the right tail sees a more rapid increase in wages than the left tail.

This may have occurred due to both composition and wage structure effects. The analyses show that composition effects play only a minor role throughout the distribution. In the 90th percentile, compositional shifts account $13 \%(0.055 / 0.430)$ of the total change in wages between 2003 and 2012 and even less in other percentiles. The only compositional factor that plays a role is education, indicating that (a very small) part of the reason why the 50th and 90th percentiles earn more in 2012 than in 2003, is that they have more highly educated workers. Moreover, all three occupational closure indicators have no compositional effect.

Wage structure effects contribute the most to wage growth in all percentiles. The total wage structure effect is largest for the 90th percentile, indicating that higher returns are the primary reason why this group earns more in 2012 than 2003. First, much of these effects lie in the constant, indicating that the selected covariates cannot explain some difference in the mean wages between 2003 and 2012. However, the wage structure effects of the covariates do explain part of the difference. First, the returns from age increase for the lowest decile, whereas the returns from education decrease. Gender plays a minor role in the changes in wage inequality in Norway. Of the occupational closure covariates, the returns from unionization increase, but mostly for the 
lowest decile, mitigating the (potentially large) growth in wage inequality. The main conclusion from the results of the unconditional quantile regressions is that occupational closure strategies play only a minor role in explaining recent trends in wage inequality in Norway.

\section{Conclusion}

This article examines the development in wage inequality in Norway and the role played by occupations. Is the growth in wage inequality in Norway-as in more liberal market economies-primarily due to increased wage differentials between occupations? Second, we investigate what specific aspects of occupations correlate with (changes in) wage inequality in Norway, focusing on three forms of institutional closure: licensure, credentialization, and unionization.

First, the results show that inequality increases from 2003 to 2012 and that higher between-occupational wage inequality account for most of the increase. In other words, the differences between mean occupational wages rise over these 10 years, and occupations are a more important predictor of workers' wages in 2012 than 2003. Nevertheless, the changes are small: only a $2 \%$ increase in between-occupational inequality per year. The analyses also reveal, however, that the within-occupation wage inequality is more important to overall variance and accounts for two-thirds of the total variance in wages. Even if Norway has relatively low inequality levels, its national trends are quite similar to those in liberal market economies such as the UK and the US. Our results are comparable to Dale-Olsen and Østbakken (2016) who found a slight increase in the overall wage inequality in Norway in 2002-2012, and a moderate increase in the top end of the wage distribution.

Second, this study examines the relationships of three forms of occupational closure to (changes in) wage inequality, particularly whether licensure, credentialization, and unionization can explain the (growing) earnings differences between and within occupations. The results show that the relative returns from licensure, as well as union density and credentialization, increase during this period, thus leading to larger betweenoccupational wage inequality. Conversely, the closure institutions is associated with lower within-occupational inequality.

The results for the unconditional quantile regression indicate that these increasing returns are quite stable across different parts of the wage distribution, with a somewhat stronger increase in the top-end of the wage distribution. Our analyses also indicate that the closure devices mainly work through differences in mean wages, and that composition effects play only a minor role in the development.

In general, the three forms of occupational closure contribute to increase betweenoccupational inequality and decreased within-occupation inequality. The move toward more local and individual-level wage bargaining from peak associations for professional labor does not change the overall effect of unions to equalize within inequality, at least not in this decade. The effects, however, are not dramatic, and the unconditional quantile regression shows that occupational closure plays only a minor role in explaining recent trends in Norwegian wage inequality.

The results indicate that occupational closure helps to understand trends in wage inequality, although it is important to acknowledge that multiple factors affect changes 
in wage differences ${ }^{6}$. The results show that occupations contribute to the explanation and are an important unit of analysis to understand why some people earn (increasingly) more than others do. While occupational closure is important for wage returns, its role in explaining overtime change in wage inequality in Norway is rather small.

Wage inequality is not the only source of inequality; inequality of wealth is considerably larger (Piketty, 2014). So, if we had used an income measure that also includes income from capital (like Dale-Olsen \& Østbakken, 2016, do), we would probably have found larger differences. Still, comparatively, wage inequality in Norway is not high, and the labor market institutions contributing to a compressed wage structure still seem to be effective. The development described in the analyses, however, indicates an ongoing shift toward greater wage inequalities that might eventually change the Nordic model (Dølvik et al., 2015).

\section{References}

Adermon, A., \& Gustavsson, M. (2015). Job Polarization and Task-Biased Technological Change: Evidence from Sweden, 1975-2005. Scandinavian Journal of Economics 117(3), 878-917.

Allison, P. D. (1978). Measures of inequality, American Sociological Review, 43(6): 865-880.

Autor, D. H., Katz, L. F., \& Kearney, M. S. (2005). Rising wage inequality: the role of composition and prices, NBER Working Paper No. 11628. National Bureau of Economic Research, Cambridge, MA.

Barth, E., Moene, K., \& Wallerstein, M. (2003). Likhet under press. Utfordringar for den skandinaviske fordelingsmodellen, [Equality under pressure: challenges to the Scandinavian redistribution model] Oslo: Gyldendal.

Bol, T., \& Drange, I. (2016). Occupational closure and wages in Norway, Acta Sociologica. DOI: https://doi.org/10.1177/0001699316659768.

Bol, T., \& Weeden, K. A. (2015). Occupational closure and wage inequality in Germany and the United Kingdom, European Sociological Review, 31(3): 354-369.

Card, D. (1998). Falling union membership and rising wage inequality: what's the connection?, NBER Working Paper No. 6520.

Cholezas, I., \& Tsakloglou, P. (2009). Earnings inequality in Europe: structure and patterns of intertemporal changes. In P. Dolton, R. Asplund, \& E. Barth (eds.), Education and Inequality Across Europe, pp. 122-146, Cheltenham, UK: Edward Elgar.

Collins, R. (1979). The credential society: an historical sociology of education and Stratification, New York: Academic Press.

Dale-Olsen, H., \& Østbakken, K. M. (2016). Økende lønnsulikhet i Norge i perioden 2002-2012?, [Growing wage inequality 2002-2012?] Søkelys på arbeidslivet, 33 (01-02): 122-141.

DiPrete, T. A., Eller, C. C., Bol, T., \& van de Werfhorst, H. G. (2017). School-to-Work Linkages in the United States, Germany, and France. American Journal of Sociology, 122(6), 1869-1938.

Dølvik, J. E., Fløtten T., Hippe, J. M., \& Jordfald, B. (2015). The Nordic model towards 2030. A new chapter? Fafo Report 2015:07, Oslo: FAFO.

Erikson, R., \& Goldthorpe, J. H. (1993). The constant flux. A study of class mobility in industrial societies, Oxford, Clarendon Press.

Fennefoss, A., \& Høgsnes, G. (2008). Lønnsoppgjøret 2008: Oppsummering og analyse, [The wage settlement 2008: summary and analysis] Søkelys på arbeidslivet, 25(3): 381-399.

Firpo, S., Fortin, N. M., \& Lemieux, T. (2009). Unconditional quantile regressions, Econo- 
metrica, 77(3): 953-973. DOI: https://doi.org/ 10.3982/ECTA6822.

Goldthorpe, J. H. (1987). Social mobility and class structure in modern Britain, $2^{\text {nd }}$ edition, Oxford: Clarendon Press.

Goos, M., Manning, A., \& Salomons, A. (2014). Explaining Job Polarization: Routine-Biased Technological Change and Offshoring. American Economic Review 104(8): 2509-2526.

Gullestad, M. (1992). The art of social relations. Essays on culture, social action and everyday life in modern Norway, Kristiansand: Scandinavian University Press.

Hjellbrekke, J., \& Korsnes O. (2014). Intergenerasjonell mobilitet og sirkulasjon i norske elitar og profesjonar [Intergenerational mobility and circulation of Norwegian elites and professions]. In O. Korsnes, M. N. Hansen, \& J. Hjellbrekke (eds.), Elite og klasse $i$ et egalitort samfunn [Elitism and class in an egalitarian society], pp. 54-76, Oslo: Universitetsforlaget.

Humphris, A., Kleiner, M., \& Koumenta, M. (2010). How does government regulate occupations in the United Kingdom and the United States? Issues and policy implications, In D. Marsden (ed.), Employment in the lean years, pp. 87-101, New York: Oxford University Press.

Jonsson, J. O., Grusky D. B., Di Carlo, M., Pollak, R., \& Brinton, M. C. (2009). Microclass mobility: social reproduction in four countries, American Journal of Sociology, 114(4): 977-1036.

Jordfald, B., \& Nymoen, R. (2016). Hva skjer nederst i lønnsfordelingen i privat sektor?, [What is going on in the bottom end of the wage distribution in the private sector?] Rapport nr 8-2016, Oslo: Senter for lønnsdannelse.

Katz, L. \& D. H. Autor (1999). Changes in the Wage Structure and Earnings Inequality. In Aschenfelter. O \& D. E. Card (eds.) Handbook of Labor Economics Vol. 3a. (pp. 1463-1555). Amsterdam: Elsevier.

Kim, C., \& Sakamoto, A. (2008). The rise of intra-occupational wage inequality in the United States, 1983 to 2002, American Sociological Review, 73(1): 129-157.

Kleiner, M. M., \& Krueger, A. B. (2010). The prevalence and effects of occupational licensing, British Journal of Industrial Relations, 48(4): 676-687. DOI: https://doi.org/10.1111/ j.1467-8543.2010.00807.x.

Lemieux, T. (2008). The changing nature of wage inequality, Journal of Population Economics, 21(1): 21-48. doi: https://doi.org/10.1007/s00148-007-0169-0.

Markussen, S., \& Røed, K. (2016). Ulikhet og sosial mobilitet, [Inequality and social mobility] in I. Frønes \& L. Kjølsrød (eds.), Det norske samfunn, Vol. 2, 7th edition, Oslo: Gyldendal Akademisk.

Mastekaasa, A. (2011). Ulikhet i arbeidsinntekter i Norge 1975-2004 mellom og innen utdanningsnivåer, [Inequality in work incomes in Norway 1975-2004 between and within educational levels] Søkelys på arbeidslivet, 28(1-2): 67-88.

Moore, W. J., Pearce, D. K., \& Wilson, R. M. (1981). The regulation of occupations and the earnings of women, Journal of Human Resources, 16(3): 366-383.

Mouw, T., \& Kalleberg, A. L. (2010). Do changes in job mobility explain the growth of wage inequality among men in the United States 1977-2005? Social Forces, 88(5): 2053-208. DOI: https://doi.org/10.1353/sof.2010.0035.

Nergaard, K., Barth, E., \& Dale-Olsen, H. (2015). Lavere organisasjonsgrad, et spørsmål om nykommere? [Declining union density rates-a matter of newcomers in the labor market?], Søkelys på arbeidslivet, 32(1-2): 91-110.

Oesch, D. (2006). Coming to grips with a changing class structure. An analysis of employment stratification in Britain, Germany, Sweden and Switzerland, International Sociology, 21(2): 263-288. DOI: https://doi.org/10.1177/0268580906061379.

Piketty, T. (2014). Capital in the twenty-first century, Cambridge, MA: The Belknap Press of Harvard University Press.

Prandy, K. (1990). The Revised Cambridge Scale of occupations, Sociology, 24(4): 629-655.

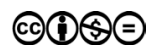


Rosenfeld, J. (2014). What unions no longer do. Cambridge, MA.: Harvard University Press.

Sørensen, A. B. (1996). The structural basis of social inequality, American Journal of Sociology, 101(5): 1333-1365.

Sørensen, A. B. (2000). Toward a sounder basis for class analysis, American Journal of Sociology, 105(6): 1523-1558.

Stiglitz,J.E. (2012). The price of inequality. How'today divided society is endangers our Future, New York: Norton \& Company.

Wallerstein, M. (1999). Wage-setting institutions and pay inequality in advanced industrial societies, American Journal of Political Science, 43(3) 649-80.

Weber, M. (1978). Economy and society: an outline of interpretive sociology, Berkeley, Calif.: University of California Press.

Weeden, K. A. (2002). Why do some occupations pay more than others? Social closure and earnings inequality in the United States, American Journal of Sociology, 108(1): 55-101.

Weeden, K. A., \& Grusky, D. B. (2005). The case for a new class map, American Journal of Sociology, 111(1): 141-212.

Weeden, K. A., \& Grusky, D. B. (2014). Inequality and market failure, American Behavioral Scientist, 58(3): 473-491. DOI: https://doi.org/10.1177/0002764213503336.

Western, B., \& Bloome, D. (2009). Variance function regressions for studying inequality, Sociological Methodology, 39(1): 293-326. DOI: https://doi.org/10.1111/j.1467-9531. 2009.01222.x.

Williams, M. (2013). Occupations and British wage inequality, 1970s-2000s, European Sociological Review, 29(4): 841-857. doi: https://doi.org/10.1093/esr/jcs063.

Wright, E. O. (1997). Class counts: comparative studies in class analysis, Cambridge: Cambridge University Press.

\section{Endnotes}

1 This, of course, is not the only source of inequality and certainly not the most important when it comes to 'the top 1 percent' of wealth. As Piketty (2014) writes, 'inequality of wealth-and of the consequent income from capital-is in fact always much greater than inequality of income from labor' (p. 40).

2 This might contribute to explaining increasing inequality between occupations if reduced unionization resulted in increasing differences between the occupations still unionized and those with weakened unions. However, alternatively, replacing collective bargaining with individual wage negotiations likely increases within-occupation differences.

3 Our discussion below has much in common with the literature on job polarisation [e.g., Adermon \& Gustavsson (2015), Goos et al. (2014), or Katz \& Autor (1999)]. Our main point here is not to review different explanations on this phenomenon, but to spell out the two main ways wage differences between occupations may change.

4 Such changes in the composition of the US labour force are described by Autor et al. (2005).

5 The Research Council of Norway (grant no. 237039) finances the Norwegian Occupational Regulations Database. Oslo and Akershus University College of Applied Sciences collect and distribute the data. These institutions are not responsible for the current analyses and interpretations of the data.

6 The regression analyses adjust for observed individual characteristics, i.e. education, gender, and age, but not for unobserved individual heterogeneity, such as ability or productivity that might affect between- and within-occupational wage inequality. 